\title{
THE EFFECT OF Y, Gd AND Ca ON THE IGNITION TEMPERATURE OF EXTRUDED MAGNESIUM ALLOYS
}

\author{
UČINEK Y, Gd IN Ca NA TEMPERATURO VŽIGA \\ EKSTRUDIRANIH MAGNEZIJEVIH ZLITIN
}

\author{
Drahomir Dvorsky $^{1 *}$, Jiri Kubasek ${ }^{1}$, Dalibor Vojtech ${ }^{1}$, Peter Minárik ${ }^{2}$, \\ Jitka Stráská ${ }^{2}$ \\ ${ }^{1}$ University of Chemistry and Technology, Prague, Faculty of Chemical Technology, Department of Metals and Corrosion Engineering, \\ Technická 516628 Praha 6 - Dejvice, Czech Republic \\ ${ }^{2}$ Department of Physics of Materials, Charles University, Ke Karlovu 5, 12116 Prague 2, Czech Republic
}

Prejem rokopisa - received: 2019-11-25; sprejem za objavo - accepted for publication: 2020-06-17

doi:10.17222/mit.2019.284

\begin{abstract}
Magnesium, as a lightweight constructional material, is suitable for application in the aviation industry. However, the use of magnesium in aircraft was banned by the Federal Aviation Administration (FAA) due to the low ignition temperature and problematic extinguishing. Nevertheless, the ban was lifted under the condition that magnesium alloys have to pass the ignition tests. Therefore, this paper is focused on the effect of $\mathrm{Y}, \mathrm{Gd}$ and $\mathrm{Ca}$ alloying elements on the mechanical, corrosion and ignition properties of low-alloyed binary and quaternary magnesium alloys. The highest increase of ignition temperature among binary alloys (by up to $120 \mathrm{~K}$ compared to pure $\mathrm{Mg}$ ) was achieved for a $\mathrm{Mg}-0.5 \mathrm{Ca}$ alloy. The excellent value of the ignition temperature $(1131 \mathrm{~K})$ was measured for the low-alloyed quaternary alloy $\mathrm{Mg}-0.5 \mathrm{Y}-0.5 \mathrm{Gd}-0.5 \mathrm{Ca}$, thanks to the synergic protective effect of oxides of all the selected alloying elements.
\end{abstract}

Keywords: magnesium alloys, ignition temperature, extrusion

Magnezij je kot lahek konstrukcijski material primeren za uporabo v letalski industriji. Vendar pa je uporaba magnezija prepovedana pri Ameriški zvezni upravi za letenje (FAA, Federal Aviation Administration) zaradi nizke temperature vžiga in problematičnega samovžiga. Kljub temu je bila prepoved pogojno preklicana, če so bili za izbrano Mg zlitino predhodno izvedeni uspešni testi vžiga. Zato so se v članku avtorji osredotočili na opis vpliva legirnih elementov (Y, Gd in Ca) na mehanske in korozijske lastnosti ter temperaturo vžiga malolegiranih binarnih in kvaternarnih magnezijevih zlitin. Največje povišanje temperature vžiga med binarnimi zlitinami so raziskovalci ugotovili (za $120 \mathrm{~K}$ v primerjavi s čistim Mg) pri zlitini $\mathrm{Mg}-0,5 \mathrm{Ca}$. Odlično temperaturo vžiga $(1131 \mathrm{~K})$ so izmerili pri malolegirani kvaternarni zlitini Mg-0,5Y-0,5Gd-0,5Ca, zahvaljujoč vzajemnem zaščitnem učinku izbranih legirnih elementov.

Keywords: magnezijeve zlitine, temperatura vžiga, ekstruzija (iztiskavanje)

\section{INTRODUCTION}

The low density $\left(1.74 \mathrm{~g} \cdot \mathrm{cm}^{-3}\right)$ of magnesium, which is $75 \%$ and $35 \%$ lower than that of iron and aluminum, respectively, makes it a prospective construction material in the aviation industry. ${ }^{1-4}$ The substitution of aluminum parts for magnesium would provide up to a $30 \%$ reduction of weight of the airplane, which would lead to reduced $\mathrm{CO}_{2}$ emissions due to the fuel savings. 5,6 The utilization of magnesium was not possible due to the ban from the Federal Aviation Administration (FAA). ${ }^{1,3}$ The ban was lifted under the condition that magnesium alloys used for this application would pass the flammability tests. It was quickly discovered that widely used AZ alloys failed flammability tests and WE43 passed the test due to the formation of a protective layer of $\mathrm{Y}_{2} \mathrm{O}_{3} \cdot{ }^{1,5}$

Specific magnesium alloys were prepared in order to make melting easier and without the necessity of a protective atmosphere as the $\mathrm{SF}_{6}$ environmental

*Corresponding author's e-mail:

dvorskyd@vscht.cz (Drahomir Dvorsky) non-friendly gas is used for melting. ${ }^{7-10}$ Moreover, such alloys exerted increased resistance to oxidation and suppressed flammability. Alloying elements like $\mathrm{Ca}, \mathrm{Be}$, $\mathrm{Gd}$, Y, and Nd greatly improve the oxidation resistance due to the creation of protective oxides on the surface. ${ }^{9,11,12}$ The effectiveness of the oxide is characterized by the Pilling-Bedworth ratio (PBR) and the Gibbs free energy change for oxidation. ${ }^{9,13}$ The surface is sufficiently protected if the PBR ratio is between 1 and 2, otherwise it is porous or with cracks. ${ }^{13}$ The Gibbs free energy for the oxidation of the alloying elements should be lower than that of the oxidation of magnesium at elevated temperature. Moreover, the alloying elements should be soluble in a magnesium solid solution, otherwise intermetallic phases have limited protective ability. ${ }^{14}$

The positive effect of rare-earth elements (REEs) and $\mathrm{Ca}$ on the ignition temperature was observed for concentrations higher than $1 w / \%$. However, higher concentrations can result in the deterioration of mechanical properties due to the occurrence of intermetallic phases..$^{15}$ On the other hand, $\mathrm{Ca}$ and $\mathrm{Y}$ can have a synergic effect on 
the ignition resistance without a deterioration of the mechanical properties. ${ }^{12,16}$

The ignition temperature could be determined by continuous heating techniques like DTA (Differential Thermal Analysis) or TGA (Thermo-Gravimetric Analysis). Other methods rely on the exposition of the sample to a direct flame in order to simulate the real scenario of fire in the aircraft. ${ }^{15}$ The ignition temperature is characterized by a sudden increase of the temperature during exposition as magnesium has a very high burning temperature and it is very problematic to extinguish. ${ }^{17}$ The instrumentation of the experiment is essential as M. Liu et al. ${ }^{18}$ measured the ignition temperature of the WE43 alloy to be $917 \mathrm{~K}$, while N. V. R. Kumar et al. ${ }^{19}$ measured $1003 \mathrm{~K}$ for the same alloy, however, with the access of air. Therefore, the presence of oxygen is a very important factor for the oxidation resistance of magnesium alloys. The sole oxygen atoms are absorbed on the surface, while larger clusters incorporate beneath the surface in the magnesium matrix. ${ }^{20,21}$

This work deals with the influence of the individual elements of the Mg-Y-Gd-Ca alloy with a low amount of alloying elements on the mechanical, corrosion and ignition properties.

\section{MATERIALS AND METHODS}

\subsection{Sample preparation}

Samples were prepared by melting the pure elements in an induction furnace at $1023 \mathrm{~K}$ for $0.5 \mathrm{~h}$ under a protective argon atmosphere $(99.96 \%)$. The melt was cast into a cold brass mold of $20 \mathrm{~mm}$ in diameter. Cylindrical samples with a height of $7 \mathrm{~mm}$ were extruded at $623 \mathrm{~K}$ with an extrusion ratio of 10 and an extrusion rate of $5 \mathrm{~mm} \cdot \mathrm{min}^{-1}$. Extruded rods had $6 \mathrm{~mm}$ in diameter and were $120 \mathrm{~mm}$ long. For further tests, the surface was turned on a lathe and the final diameter was $5 \mathrm{~mm}$.

Table 1: The EDS analysis of the composition of prepared alloys $(w / \%)$

\begin{tabular}{|c|c|c|c|}
\hline & $\mathrm{Y}$ & $\mathrm{Gd}$ & $\mathrm{Ca}$ \\
\hline $\mathrm{Mg}-0.5 \mathrm{Y}$ & $0.5 \pm 0.1$ & - & - \\
\hline $\mathrm{Mg}-0.5 \mathrm{Gd}$ & - & $0.4 \pm 0.1$ & - \\
\hline $\mathrm{Mg}-0.5 \mathrm{Ca}$ & - & - & $0.3 \pm 0.1$ \\
\hline $\mathrm{Mg}-0.5 \mathrm{Y}-0.5 \mathrm{Gd}-0.5 \mathrm{Ca}$ & $0.5 \pm 0.1$ & $0.5 \pm 0.1$ & $0.2 \pm 0.1$ \\
\hline
\end{tabular}

\subsection{Microstructure characterization}

Samples were firstly ground on $\mathrm{SiC}$ papers P80-P4000, afterwards they were polished on diamond pastes D2 and D0.7 (UR-diamant). The final polishing was performed with an Eposil F suspension. The microstructure was characterized with a scanning electron microscope SEM TescanVEGA3 having energy-dispersive spectrometry (Oxford EDS, AZtec). Image analyses of the phase volume were made with ImageJ software.

\subsection{Mechanical properties}

Compressive testing was carried out on cylindrical samples with a diameter of $5 \mathrm{~mm}$ and $7 \mathrm{~mm}$ high using LabTest 5.250SP1-VM at room temperature at a strain rate of $0.001 \mathrm{~s}^{-1}$. Compressive yield strength (CYS), ultimate compressive strength (UCS) and deformation to fracture were determined from the compression curves.

\subsection{Immersion tests}

Cylindrical samples with a diameter of $5 \mathrm{~mm}$ and $7 \mathrm{~mm}$ high were ground on all sides on SiC paper P2500. Samples were attached in the plastic holders and immersed in the $3 w / \% \mathrm{NaCl}$ solution at room temperature for $7 \mathrm{~d}$. The corrosion rate was calculated from the weight changes after the removal of the corrosion products in the solution containing $200 \mathrm{~g} \cdot \mathrm{L}^{-1} \mathrm{CrO}_{3}$, $10 \mathrm{~g} \cdot \mathrm{L}^{-1} \mathrm{AgNO}_{3}$ and $20 \mathrm{~g} \cdot \mathrm{L}^{-1} \mathrm{Ba}\left(\mathrm{NO}_{3}\right)_{2}$.

\subsection{Ignition temperature measurement}

The surfaces of the samples with diameter of $5 \mathrm{~mm}$ and hieght of $15 \mathrm{~mm}$ were finished by grinding on the paper P1200. Subsequently, the samples were put in an $\mathrm{Al}_{2} \mathrm{O}_{3}$ crucible, which was inserted into the resistance furnace. The instrumentation is similar to the work of Aydin et al. ${ }^{17}$ and it is shown in Figure 1.

One thermocouple was in direct contact with the sample and the other one was in the middle of the crucible. There was a tube with an airflow on the other side of the crucible. Technical air with an airflow of $100 \mathrm{~L} \cdot \mathrm{h}^{-1}$ was used to supply the crucible with oxygen. The heat rate of the furnace was set to $35 \mathrm{~K} \cdot \mathrm{min}^{-1}$; however, due to the heat transmission and the partial cooling with the technical air, the real heating rate for the sample was about $25 \mathrm{~K} \cdot \mathrm{min}^{-1}$. The temperature increased with time until it rose rapidly due to the ignition of the sample. Each sample was measured three times. After the identification of the ignition temperatures, selected

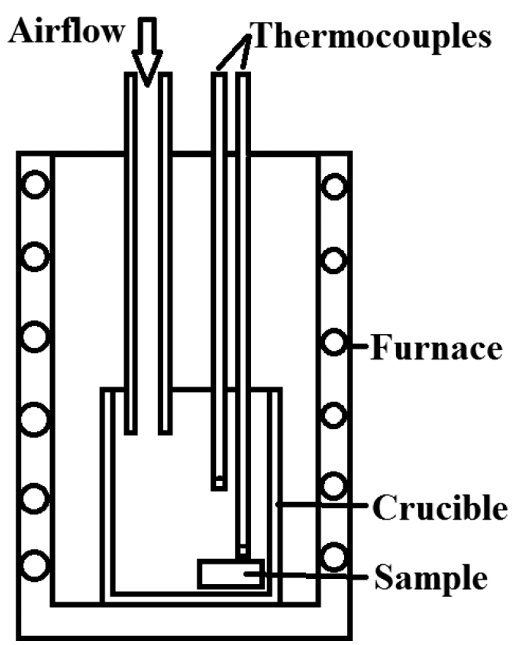

Figure 1: Instrumentation for the measurement of ignition temperatures 
samples were exposed at the same furnace temperature of $923 \mathrm{~K}$. When the temperature on the surface of the sample surface reached the required value, samples were immediately removed from the furnace and cooled in the air. The formed surface oxide layer was studied using SEM with EDS. For this purpose, samples were mounted into the epoxy resin and ground and polished under ethanol in order not to damage the oxide layer.

\section{RESULTS AND DISCUSSION}

\subsection{Microstructure characterization}

The microstructures of the extruded ingots are shown in Figure 2. One can see that the microstructures of all the samples are very similar and they all contain intermetallic phases. Unfortunately, due to the low amount of intermetallic phases $(0.5-1.0 \mathrm{vol} \%$ according to the image analysis), they could not be detected by XRD analysis. Therefore, detailed EDS analysis of the phases was performed at $10 \mathrm{kV}$ in order to reduce the analysed area. With EDS analysis of the individual phases and knowledge of the $\mathrm{Mg}-\mathrm{Y}$ phase diagram, we can presume that the phase containing $\approx 30 \mathrm{w} / \%$ of $\mathrm{Y}$ in $\mathrm{Mg}-0.5 \mathrm{Y}$ alloy is $\mathrm{Mg}_{24} \mathrm{Y}_{5}$ with typical cubic shape (Figure 2a), even though a similar-looking cubic-shaped phase containing $\mathrm{Y}$ was recently identified as $\mathrm{YH}_{3} .^{22,23}$ The $\mathrm{Mg}-0.5 \mathrm{Gd}$ alloy contained roughly the same amount of intermetallic phases as the previous alloy and the phases were according to the phase diagram and EDS analysis $\left(\approx 20 \mathrm{w} / \%\right.$ of $\mathrm{Gd}$ ) identified as $\mathrm{Mg}_{5} \mathrm{Gd}$ (Figure $\left.2 \mathbf{b}\right) .{ }^{24} \mathrm{In}$ the case of the $\mathrm{Mg}-0.5 \mathrm{Ca}$ alloy, there was a slightly lower amount of intermetallic phases due to the lower content of $\mathrm{Ca}$. The lower content of $\mathrm{Ca}$ was selected due to the lower solubility of $\mathrm{Ca}$ in the magnesium solid solution. The presented intermetallic phases were $\mathrm{Mg}_{2} \mathrm{Ca}$ $(\approx 0.7 w / \%$ of $\mathrm{Ca})$. Unfortunately, due to the lower standard reduction potential of alloying elements in these phases compared to the $\mathrm{Mg}$, those phases are more noble, and therefore, are preferentially etched from the matrix (Figure 2c). ${ }^{25}$ The quaternary alloy contained all the phases specified for the binary alloys (Figure 2d). Nevertheless, the majority of the alloying elements $(0.2-0.4 w / \%)$ was dissolved in the magnesium solid solution in all cases. Exact values are summarized in

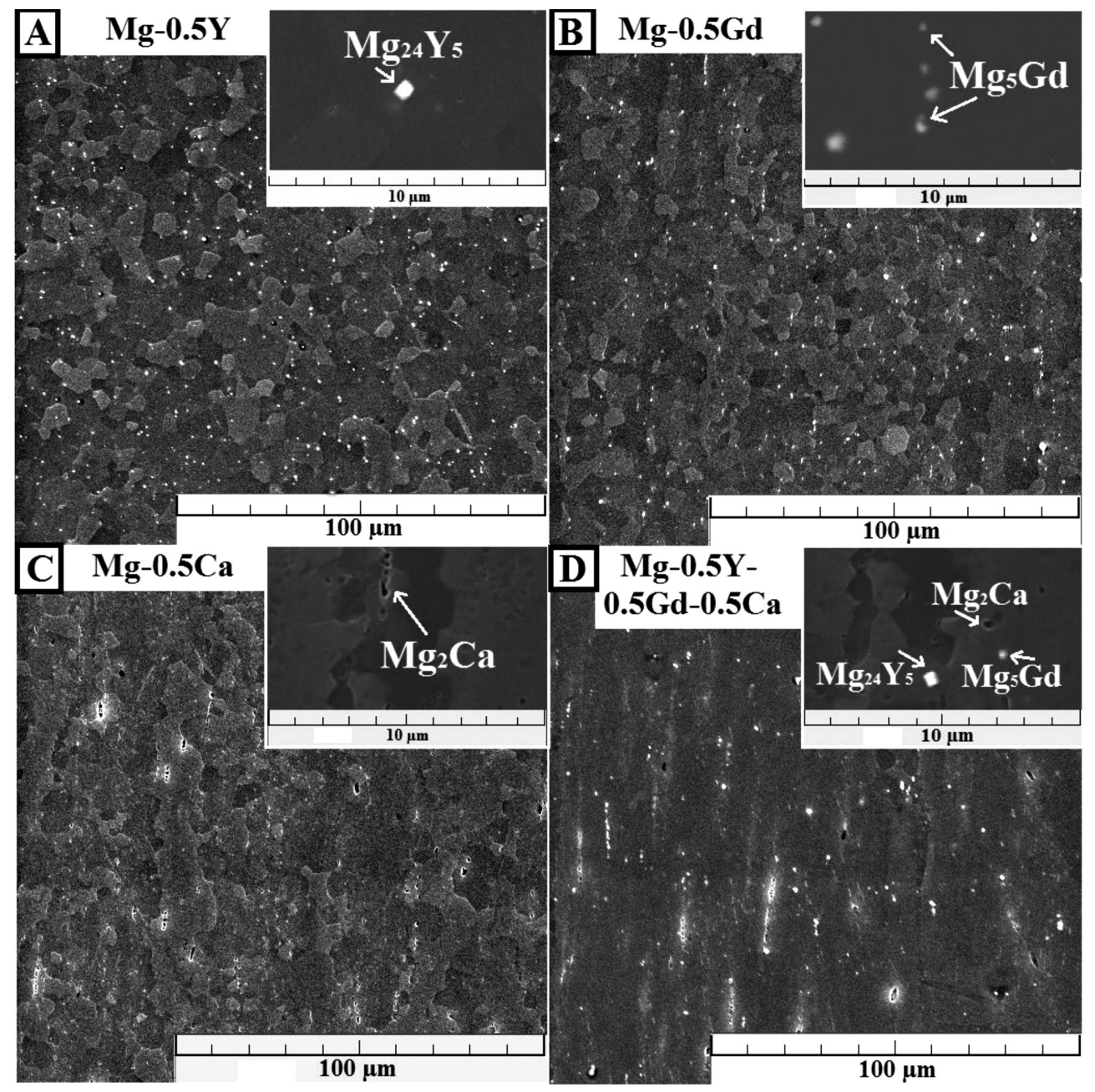

Figure 2: Microstructures and details of intermetallic phases of the extruded alloys: a) $\mathrm{Mg}-0.5 \mathrm{Y}$, b) $\mathrm{Mg}-0.5 \mathrm{Gd}$, c) $\mathrm{Mg}-0.5 \mathrm{Ca}$, d) $\mathrm{Mg}-0.5 \mathrm{Y}-0.5 \mathrm{Gd}-0.5 \mathrm{Ca}$ 
Table 2: Summarized properties of extruded alloys

\begin{tabular}{|c|c|c|c|c|}
\hline & $\mathrm{Mg}-0.5 \mathrm{Y}$ & $\mathrm{Mg}-0.5 \mathrm{Gd}$ & $\mathrm{Mg}-0.5 \mathrm{Ca}$ & $\mathrm{Mg}-0.5 \mathrm{Y}-0.5 \mathrm{Gd}-0.5 \mathrm{Ca}$ \\
\hline $\mathrm{X}$ in solid solution $(w / \%)$ & $0.4 \pm 0.1$ & $0.3 \pm 0.1$ & $0.2 \pm 0.1$ & $0.2 / 0.3 / 0.2$ \\
\hline CYS $(\mathrm{MPa})$ & $118 \pm 4$ & $108 \pm 3$ & $132 \pm 2$ & $163 \pm 2$ \\
\hline UCS $(\mathrm{MPa})$ & $384 \pm 5$ & $363 \pm 5$ & $393 \pm 3$ & $433 \pm 3$ \\
\hline Relative deformation $(\%)$ & $16 \pm 1$ & $18 \pm 1$ & $16 \pm 1$ & $14 \pm 1$ \\
\hline Corrosion rate $\left(\mathrm{mm} \cdot \mathrm{y}^{-1}\right)$ & $0.76 \pm 0.32$ & $0.53 \pm 0.15$ & $0.63 \pm 0.11$ & $0.38 \pm 0.02$ \\
\hline Ignition temperature $(\mathrm{K})$ & $981 \pm 4$ & $1041 \pm 5$ & $1056 \pm 5$ & $1131 \pm 6$ \\
\hline
\end{tabular}

Table 2. The grains of all the materials were equiaxed and the size ranged between $5 \mu \mathrm{m}$ and $15 \mu \mathrm{m}$.

\subsection{Mechanical properties}

Representative compression curves of the extruded ingots are summarized in Figure 3. One can see that the binary alloys were characterized by only slightly different mechanical behaviour. This is due to the similar amount of alloying elements dissolved in the solid solution, as it is considered as the main increment that improves the mechanical properties in this case. The solid-solution strengthening is associated with different atomic diameters compared to the matrix. ${ }^{26}$ The diameter of magnesium is $0.16 \mathrm{~nm}$, while $\mathrm{Y}, \mathrm{Gd}$ and $\mathrm{Ca}$ have $0.18 \mathrm{~nm}$. The difference of $12 \%$ has an impact on the mechanical strengthening; ${ }^{27}$ however, due to the same diameter of alloying elements, the compressive yield strength should be also similar. On the other hand, the solid-solution strengthening also depends on the shear modulus of the alloying elements according to Equation (1), ${ }^{26}$ where $\eta$ is the approximate shear modulus of the binary alloy, $G_{1}$ is the shear modulus of the alloying element $\left(G_{\mathrm{Y}}=26.0 \mathrm{GPa}, G_{\mathrm{Gd}}=22.0 \mathrm{GPa}, G_{\mathrm{Ca}}=7.4 \mathrm{GPa}\right)$ and $G$ is the shear modulus of magnesium $\left(G_{\mathrm{Mg}}=\right.$ $17.0 \mathrm{~Pa}) .^{27,28}$

$$
\eta=2 \mathrm{l}\left(G_{1}-G\right) \mathrm{I} \cdot\left(G_{1}+G\right)^{-1}
$$

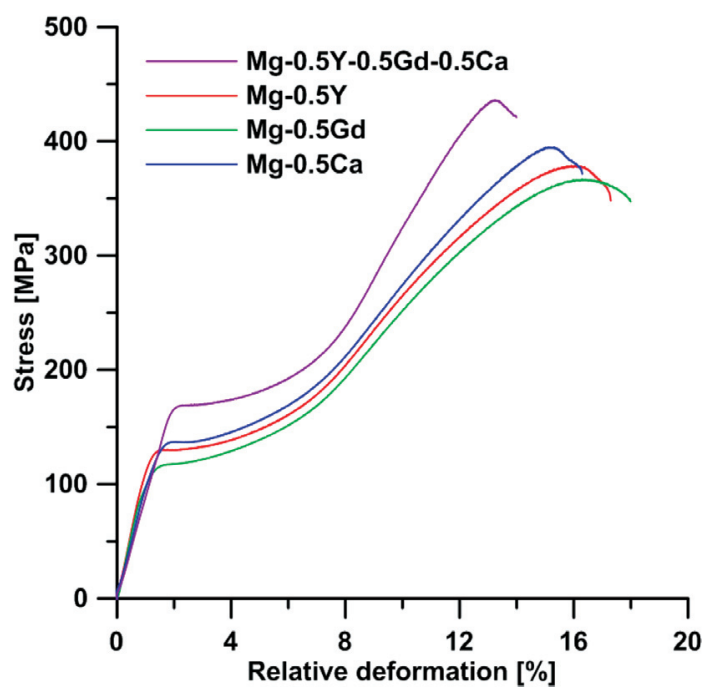

Figure 3: Compressive curves of extruded materials
According to Equation (1), the highest shear modulus of a binary alloy is for the $\mathrm{Ca}$, which is in accordance with the measured values. Similar compressive properties were measured for the Mg-0.5Y alloy, even though the shear modulus for this alloy is almost half of the $\mathrm{Mg}-0.5 \mathrm{Ca}$. This might be associated with the amount of yttrium in the solid solution, which is double the amount of $\mathrm{Ca}$ in the $\mathrm{Mg}-0.5 \mathrm{Ca}$ alloy. The $\mathrm{Mg}-0.5 \mathrm{Gd}$ alloy contained slightly more alloying elements in the solid solution than the $\mathrm{Mg}-0.5 \mathrm{Ca}$ alloy; however, the shear modulus for this alloy was more than three times lower, and therefore, the effect of the solid-solution strengthening is the lowest among the measured materials. The quaternary alloy exerted the best compressive properties as it contained the most alloying elements in the solid solution $(0.7 \mathrm{w} / \%)$.

\subsection{Immersion tests}

Immersion tests were performed in $3 w / \% \mathrm{NaCl}$ solution at room temperature for 7 days. The corrosion rates calculated from the weight changes after removal of the corrosion products are summarized in Table 2. One can see that the binary alloys were characterized by relatively similar corrosion rates. Even though yttrium and gadolinium are known to reduce the corrosion rate through the formation of more stable corrosion products on the surface, the concentration presented in the prepared alloys was probably too low to take the proper effect. In contrast, the presented intermetallic phases can work as cathodes or anodes, depending on their potential compared to the $\mathrm{Mg}$ matrix. ${ }^{22}$ Intermetallic phases containing $\mathrm{Y}$ and Gd are characterized by only slightly higher standard reduction potential compared to the $\mathrm{Mg}$. Therefore, $\mathrm{Mg}_{24} \mathrm{Y} 5$ and $\mathrm{Mg}_{5} \mathrm{Gd}$ work as cathodic sites and slightly increase the corrosion rate of the $\mathrm{Mg}$ matrix. In contrast, $\mathrm{Mg}_{2} \mathrm{Ca}$ is characterised with a lower standard reduction potential than pure $\mathrm{Mg}$, and therefore, the intermetallic phases corrode preferentially, providing cathodic protection for the $\mathrm{Mg}$ matrix. ${ }^{29}$ Nevertheless, the lowest corrosion rate was measured for the quaternary alloy due to the combined effect of $\mathrm{Y}$ and $\mathrm{Gd}$, which provides stable protective oxide layers on the interface of material and immersion solution. 


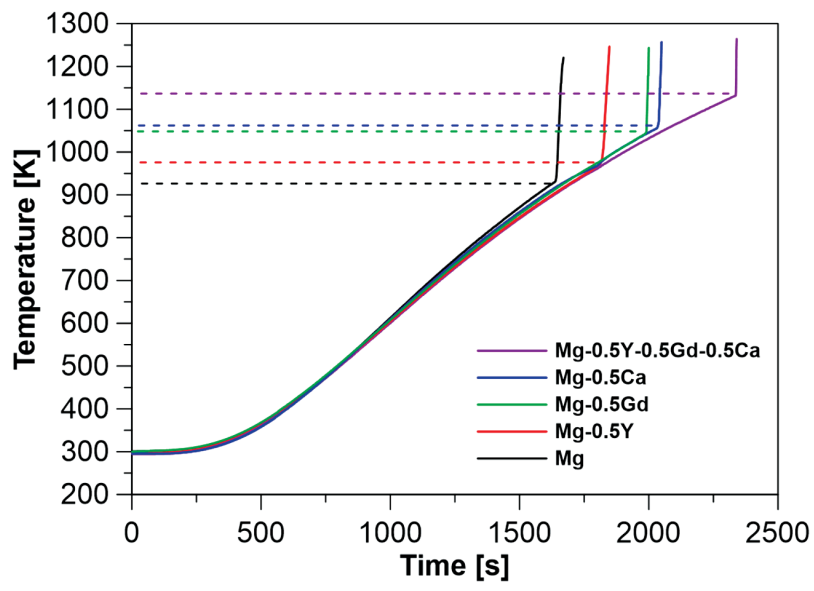

Figure 4: Increase of temperature with time for measured samples under an airflow $\left(100 \mathrm{~L} \cdot \mathrm{h}^{-1}\right)$ with a heating rate of $25 \mathrm{~K} \cdot \mathrm{min}^{-1}$

\subsection{Ignition temperature characterization}

The measurement of the ignition temperature was performed three times for each sample, while the differences between individual measurements were negligible. Representative curves of the temperatures against the time for individual specimens are summarized in Figure 4.

The highest increase of the ignition temperature for binary alloys was observed after a $\mathrm{Ca}$ addition. Even a small addition of $0.3 w / \%$ was enough to increase the ignition temperature of the $\mathrm{Mg}$ by almost $200 \mathrm{~K}$. The improved ignition temperature is due to the formation of $\mathrm{CaO}$ on the surface of the sample during heating (Figure 5c), which effectively protects the bulk Mg. The $\mathrm{CaO}$ is formed on the surface due to the lower free Gibbs energy of $\mathrm{CaO}$ formation compared to the formation of $\mathrm{MgO}$. An yttrium addition was reported to significantly improve the ignition properties; however, only in high contents, which subsequently deteriorate the mechanical properties due to the formation of intermetallic phases. ${ }^{15,30} \mathrm{Y}$ is able to form the layer of $\mathrm{Y}_{2} \mathrm{O}_{3}$ on the surface (Figure 5a), which sufficiently protects the $\mathrm{Mg}$ against burning. The $0.5 w / \%$ of Gd addition was almost as effective as the addition of $\mathrm{Ca}$. Again, the protective oxide layer of $\mathrm{Gd}_{2} \mathrm{O}_{3}$ (Figure $\mathbf{5} \mathbf{b}$ ) was responsible for the improved ignition properties. A relatively high ignition temperature of $1131 \mathrm{~K}$ was measured for the quaternary alloy. Such a high ignition temperature is achieved due to the synergic effect of the individual elements (Fig-
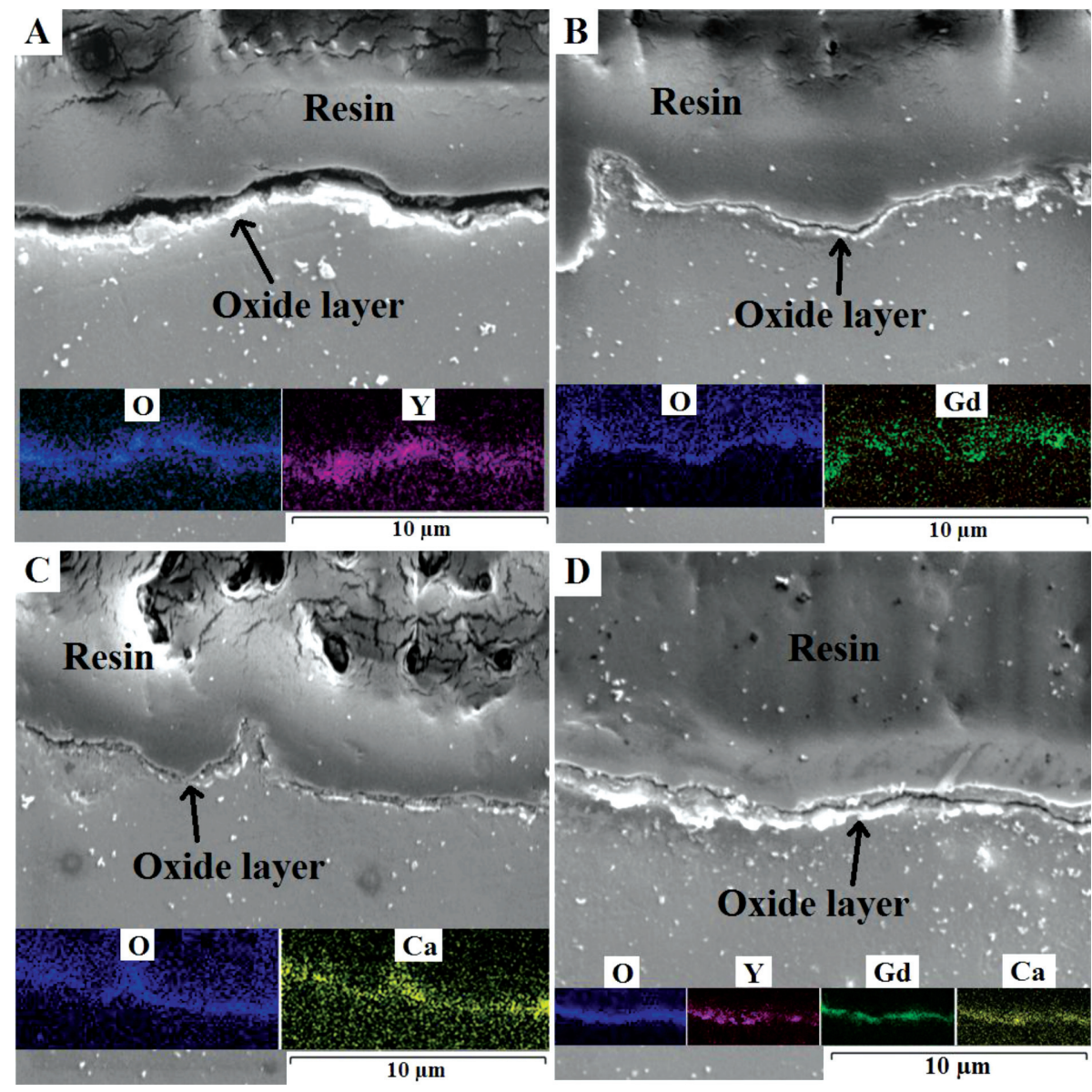

Figure 5: EDS analysis of the cuts of samples after exposure to $923 \mathrm{~K}$ for extruded alloys: a) $\mathrm{Mg}-0.5 \mathrm{Y}$, b) $\mathrm{Mg}-0.5 \mathrm{Gd}$, c) $\mathrm{Mg}-0.5 \mathrm{Ca}$, d) $\mathrm{Mg}-0.5 \mathrm{Y}-0.5 \mathrm{Gd}-0.5 \mathrm{Ca}$ 
ure 5d). N. Zhou et al. ${ }^{7}$ showed the great synergic effect of $\mathrm{Y}$ and $\mathrm{Ca}$, where the addition of $0.2 w / \%$ of $\mathrm{Ca}$ to the $\mathrm{Mg}-5 \mathrm{Y}-0.1 \mathrm{Ca}$ alloy improved the ignition temperature to a value of $1213 \mathrm{~K}$. Nevertheless, the quaternary alloy presented in this work contains only $1.2 \mathrm{w} / \%$ of alloying elements in sum compared to the $5.3 \mathrm{w} / \%$ mentioned in the previous work. Out of the results, we can deduce that the synergic effect is very important, as individual elements make multilayer oxides on the surface, which work as barriers and protect the material against oxidation.

The measured ignition temperatures are compared with similar alloy systems or with systems with a low amount of alloying elements found in literature sources in Table 2. Based on the comparison with literature sources 7,10,12,13,15-18,31-33 the highest measured ignition point $(1131 \mathrm{~K})$ is measured for the $\mathrm{Mg}-0.5 \mathrm{Y}-0.5 \mathrm{Gd}-$ $0.5 \mathrm{Ca}$ alloy presented in this study. The $\mathrm{Mg}-3.5 \mathrm{Y}-0.5 \mathrm{Ca}$ alloy measured by J. F. Fan et al. ${ }^{33}$ was characterized by a similar ignition temperature of $1120 \mathrm{~K}$. However, the amount of alloying elements is three times higher, and therefore, the price for such an alloy would also be higher.

Table 2: Ignition temperatures of prepared alloys compared with the literature

\begin{tabular}{|c|c|c|c|}
\hline & $\begin{array}{l}\text { Ignition } \\
\text { temper- } \\
\text { ature }\end{array}$ & Conditions & Reference \\
\hline $\begin{array}{c}\mathrm{Mg}-0.5 \mathrm{Y}-0.5 \mathrm{Gd}- \\
0.5 \mathrm{Ca}\end{array}$ & $1131 \mathrm{~K}$ & Airflow in furnace & This work \\
\hline $\mathrm{Mg}-0.5 \mathrm{Y}$ & $981 \mathrm{~K}$ & Airflow in furnace & This work \\
\hline $\mathrm{Mg}-0.5 \mathrm{Gd}$ & $1041 \mathrm{~K}$ & Airflow in furnace & This work \\
\hline $\mathrm{Mg}-0.5 \mathrm{Ca}$ & $1056 \mathrm{~K}$ & Airflow in furnace & This work \\
\hline $\mathrm{Mg}$ & $931 \mathrm{~K}$ & Airflow in furnace & This work \\
\hline $\mathrm{Mg}-1.1 \mathrm{Y}$ & $916 \mathrm{~K}$ & TG/DTA & 10 \\
\hline $\mathrm{Mg}-2.2 \mathrm{Y}$ & $914 \mathrm{~K}$ & TG/DTA & 10 \\
\hline $\mathrm{Mg} 1.6 \mathrm{Y}-1 \mathrm{Ca}$ & $955 \mathrm{~K}$ & TG/DTA & 33 \\
\hline $\mathrm{Mg}-2.5 \mathrm{Y}-0.6 \mathrm{Ca}$ & $960 \mathrm{~K}$ & TG/DTA & 33 \\
\hline Mg-3Y-0.9Ca & $1085 \mathrm{~K}$ & TG/DTA & 33 \\
\hline $\mathrm{Mg}-3.5 \mathrm{Y}-0.3 \mathrm{Ca}$ & $1090 \mathrm{~K}$ & TG/DTA & 33 \\
\hline $\mathrm{Mg}-3.5 \mathrm{Y}-0.5 \mathrm{Ca}$ & $1120 \mathrm{~K}$ & TG/DTA & 33 \\
\hline $\mathrm{Mg}$ & $933 \mathrm{~K}$ & Tube furnace on air & 7 \\
\hline $\mathrm{Mg}-1.5 \mathrm{Y}$ & $977 \mathrm{~K}$ & Tube furnace on air & 7 \\
\hline $\mathrm{Mg}-3 \mathrm{Y}$ & $1091 \mathrm{~K}$ & Tube furnace on air & 7 \\
\hline $\mathrm{Mg}-0.3 \mathrm{Nd}$ & $933 \mathrm{~K}$ & Airflow in furnace & 17 \\
\hline $\mathrm{Mg}-0.5 \mathrm{Nd}$ & $1043 \mathrm{~K}$ & Airflow in furnace & 17 \\
\hline $\mathrm{Mg}-1 \mathrm{Nd}$ & $1033 \mathrm{~K}$ & Airflow in furnace & 17 \\
\hline $\mathrm{Mg}-1.5 \mathrm{Nd}$ & $1053 \mathrm{~K}$ & Airflow in furnace & 17 \\
\hline $\mathrm{Mg}-2 \mathrm{Nd}$ & $1048 \mathrm{~K}$ & Airflow in furnace & 17 \\
\hline $\mathrm{Mg}-0.3 \mathrm{Ca}$ & $1007 \mathrm{~K}$ & Furnace on air & 16 \\
\hline $\mathrm{Mg}-0.9 \mathrm{Ca}$ & $1007 \mathrm{~K}$ & Furnace on air & 16 \\
\hline $\mathrm{Mg}-1.2 \mathrm{Ca}$ & $1093 \mathrm{~K}$ & Furnace on air & 16 \\
\hline $\mathrm{Mg}-3.5 \mathrm{Y}-0.3 \mathrm{Ca}$ & $1090 \mathrm{~K}$ & Furnace on air & 16 \\
\hline $\mathrm{Mg}-3 \mathrm{Gd}$ & $980 \mathrm{~K}$ & Furnace on air & 13 \\
\hline
\end{tabular}

\section{CONCLUSION}

The microstructures of the extruded Mg-0.5X $(x=$ $\mathrm{Ca}, \mathrm{Y}, \mathrm{Gd})$ binary alloys and the Mg-0.5Gd-0.5Y-0.5Ca quaternary alloy were characterized by recrystallised microstructures with similar grain sizes of about $10 \mu \mathrm{m}$ in diameter. Due to the similarities in the material microstructure conditions, the mechanical properties differ only slightly; however, higher values of CYS and UCS were measured for the $\mathrm{Mg}-0.5 \mathrm{Gd}-0.5 \mathrm{Y}-0.5 \mathrm{Ca}$, especially due to the higher total concentration of alloying elements in the solid solution. The corrosion rate of the $\mathrm{Mg}-0.5 \mathrm{Gd}-0.5 \mathrm{Y}-0.5 \mathrm{Ca}$ was superior to the binary systems, which is related to the synergic protection effect of the oxide layers of $\mathrm{Y}$ and $\mathrm{Gd}$ on the surface. The ignition temperature was increased by $50 \mathrm{~K}$ due to the addition of $0.5 \mathrm{w} / \%$ of Y. A greater improvement (by up to $120 \mathrm{~K}$ ) was achieved by the addition of $\mathrm{Ca}$ and Gd. Nevertheless, the best improvement of ignition temperature (by up to $200 \mathrm{~K}$ ) was due to the synergic effect of $\mathrm{Y}, \mathrm{Gd}$ and $\mathrm{Ca}$ in the quaternary alloy.

\section{Acknowledgment}

The authors wish to thank the Czech Science Foundation (project no. GA19-08937S) and specific university research (A1_FCHT_2020_003 and A2_FCHT_2020_027) for the financial support of this research. Peter Minárik acknowledges partial financial support by ERDF under project No. CZ.02.1.01/0.0/0.0/15 003/0000485.

\section{REFERENCES}

${ }^{1}$ C. Liu, S. Lu, Y. Fu, H. Zhang, Flammability and the oxidation kinetics of the magnesium alloys AZ31, WE43, and ZE10, Corrosion Science, 100 (2015), 177-185, doi:10.1016/j.corsci.2015.07.020

${ }^{2}$ T.-S. Shih, J.-B. Liu, P.-S. Wei, Oxide films on magnesium and magnesium alloys, Materials Chemistry and Physics, 104 (2007) 2, 497-504, doi:10.1016/j.matchemphys.2007.04.010

${ }^{3}$ M. Mondet, E. Barraud, S. Lemonnier, J. Guyon, N. Allain, T. Grosdidier, Microstructure and mechanical properties of AZ91 magnesium alloy developed by Spark Plasma Sintering, Acta Materialia, 119 (2016), 55-67, doi:10.1016/j.actamat.2016.08.006

${ }^{4}$ S. Tekumalla, L. Si Chun, M. Gupta, Preprocessing of powder to enhance mechanical and thermal response of bulk magnesium, Metal Powder Report, 74 (2019) 3, 137-140, doi:10.1016/j.mprp.2019. 03.003

${ }^{5}$ S. Tekumalla, M. Gupta, An insight into ignition factors and mechanisms of magnesium based materials: A review, Materials \& Design, 113 (2017), 84-98, doi:10.1016/j.matdes.2016.09.103

${ }^{6} \mathrm{~F}$. Czerwinski, Controlling the ignition and flammability of magnesium for aerospace applications, Corrosion Science, 86 (2014), 1-16, doi:10.1016/j.corsci.2014.04.047

${ }^{7}$ N. Zhou, Z. Zhang, J. Dong, L. Jin, W. Ding, Selective oxidation behavior of an ignition-proof $\mathrm{Mg}-\mathrm{Y}-\mathrm{Ca}-\mathrm{Ce}$ alloy, Journal of Rare Earths, 31 (2013) 10, 1003-1008, doi:10.1016/S1002-0721(13) 60021-6

${ }^{8}$ F. Pan, M. Yang, X. Chen, A Review on Casting Magnesium Alloys: Modification of Commercial Alloys and Development of New Alloys, Journal of Materials Science \& Technology, 32 (2016) 12, 1211-1221, doi:10.1016/j.jmst.2016.07.001 
${ }^{9}$ Z. L. Ning, X. Y. Zhao, A. A. Luo, H. H. Liu, W. Z. Liang, Y. J. Huang, F. Y. Cao, J. F. Sun, The melt protection mechanism of an $\mathrm{SO}_{2} / \mathrm{CO}_{2}$ gas mixture for a magnesium-rare-earth based alloy, Journal of Alloys and Compounds, 722 (2017), 101-107, doi:10.1016/j.jallcom.2017.06.015

${ }^{10}$ J. Fan, Z. Chen, W. Yang, S. Fang, B. Xu, Effect of yttrium, calcium and zirconium on ignition-proof principle and mechanical properties of magnesium alloys, Journal of Rare Earths, 30 (2012) 1, 74-78, doi:10.1016/S1002-0721(10)60642-4

${ }^{11}$ X. Yu, S. Shen, B. Jiang, Z. Jiang, H. Yang, F. Pan, The effect of the existing state of $\mathrm{Y}$ on high temperature oxidation properties of magnesium alloys, Applied Surface Science, 370 (2016), 357-363, doi:10.1016/j.apsusc.2016.02.156

${ }^{12}$ Y. Go, S. M. Jo, S. H. Park, H. S. Kim, B. S. You, Y. M. Kim, Microstructure and mechanical properties of non-flammable Mg-8Al-0.3Zn-0.1Mn-0.3Ca-0.2Y alloy subjected to low-temperature, low-speed extrusion, Journal of Alloys and Compounds, 739 (2018), 69-76, doi:10.1016/j.jallcom.2017.12.229

${ }^{13}$ Y. M. Kim, C. D. Yim, H. S. Kim, B. S. You, Key factor influencing the ignition resistance of magnesium alloys at elevated temperatures, Scripta Materialia, 65 (2011) 11, 958-961, doi:10.1016/j.scriptamat. 2011.08.019

${ }^{14}$ J.-S. Rao, H.-J. Li, H.-S. Xue, Ignition-proof mechanism of ZM5 magnesium alloy added with rare earth, Journal of Central South University of Technology, 17 (2010) 1, 28-33

${ }^{15}$ G. Han, D. Chen, G. Chen, J. Huang, Development of non-flammable high strength extruded $\mathrm{Mg}$-Al-Ca-Mn alloys with high $\mathrm{Ca} / \mathrm{Al}$ ratio, Journal of Materials Science \& Technology, 34 (2018) 11, 2063-2068, doi:10.1016/j.jmst.2018.03.019

${ }^{16}$ J. Fan, C. Yang, B. Xu, Effect of $\mathrm{Ca}$ and $\mathrm{Y}$ additions on oxidation behavior of magnesium alloys at high temperatures, Journal of Rare Earths, 30 (2012) 5, 497-502, doi:10.1016/S1002-0721(12)60079-9

${ }^{17}$ D. S. Aydin, Z. Bayindir, M. Hoseini, M. O. Pekguleryuz, The high temperature oxidation and ignition behavior of $\mathrm{Mg}-\mathrm{Nd}$ alloys part $\mathrm{I}$ : The oxidation of dilute alloys, Journal of Alloys and Compounds, 569 (2013), 35-44, doi:10.1016/j.jallcom.2013.03.130

${ }^{18}$ M. Liu, D. S. Shih, C. Parish, A. Atrens, The ignition temperature of Mg alloys WE43, AZ31 and AZ91, Corrosion Science, 54 (2012), 139-142, doi:10.1016/j.corsci.2011.09.004

${ }^{19}$ N. V. Ravi Kumar, J. J. Blandin, M. Suéry, E. Grosjean, Effect of alloying elements on the ignition resistance of magnesium alloys, Scripta Materialia, 49 (2003) 3, 225-230, doi:10.1016/S13596462(03)00263-X

${ }^{20}$ C. Bungaro, C. Noguera, P. Ballone, W. Kress, Early oxidation stages of $\mathrm{Mg}$ (0001): A density functional study, Physical Review Letters, 79 (1997) 22, 4433

${ }^{21}$ E. Schröder, Interaction effects in magnesium oxidation: a lattice-gas simulation, Computational materials science, 24 (2002) 1-2, $105-110$
${ }^{22}$ J. Kubásek, D. Dvorský, M. Čavojský, D. Vojtěch, N. Beronská, M. Fousová, Superior Properties of Mg-4Y-3RE-Zr Alloy Prepared by Powder Metallurgy, Journal of Materials Science \& Technology, 33 (2017) 7, 652-660, doi:10.1016/j.jmst.2016.09.019

${ }^{23}$ P. Minárik, M. Zemková, F. Lukáč, J. Bohlen, M. Knapek, R. Král, Microstructure of the novel biomedical $\mathrm{Mg}-4 \mathrm{Y}-3 \mathrm{Nd}$ alloy prepared by spark plasma sintering, Journal of Alloys and Compounds, 819 (2020), 153008, doi:10.1016/j.jallcom.2019.153008

${ }^{24}$ X. Tong, L. Zai, G. You, H. Wu, H. Wen, S. Long, Effects of bonding temperature on microstructure and mechanical properties of diffusion-bonded joints of as-cast $\mathrm{Mg}-\mathrm{Gd}$ alloy, Materials Science and Engineering: A, 767 (2019), 138408, doi:10.1016/j.msea. 2019.138408

${ }^{25}$ Y. Chai, B. Jiang, J. Song, Q. Wang, J. He, J. Zhao, G. Huang, Z. Jiang, F. Pan, Role of Al content on the microstructure, texture and mechanical properties of $\mathrm{Mg}-3.5 \mathrm{Ca}$ based alloys, Materials Science and Engineering: A, 730 (2018), 303-316, doi:10.1016/j.msea. 2018.06.011

${ }^{26} \mathrm{P}$. Lukáč, Solid solution hardening in Mg-Cd single crystals, Physica Status Solidi (A), 131 (1992) 2, 377-390, doi:10.1002/pssa. 2211310212

${ }^{27}$ L. Gao, R. S. Chen, E. H. Han, Solid solution strengthening behaviors in binary $\mathrm{Mg}-\mathrm{Y}$ single phase alloys, Journal of Alloys and Compounds, 472 (2009) 1, 234-240, doi:10.1016/j.jallcom. 2008.04.049

${ }^{28}$ https://periodictable.com/Properties/A/ShearModulus.an.html (accessed 11.11.2019).

${ }^{29}$ T. Cain, L. G. Bland, N. Birbilis, J. R. Scully, A Compilation of Corrosion Potentials for Magnesium Alloys, CORROSION, 70 (2014) 10, 1043-1051, doi:10.5006/1257

${ }^{30}$ J. Liu, D. Bian, Y. Zheng, X. Chu, Y. Lin, M. Wang, Z. Lin, M. Li, Y. Zhang, S. Guan, Comparative in vitro study on binary Mg-RE (Sc, Y, $\mathrm{La}, \mathrm{Ce}, \mathrm{Pr}, \mathrm{Nd}, \mathrm{Sm}, \mathrm{Eu}, \mathrm{Gd}, \mathrm{Tb}, \mathrm{Dy}, \mathrm{Ho}, \mathrm{Er}, \mathrm{Tm}, \mathrm{Yb}$ and Lu) alloy systems, Acta Biomaterialia, (2019), doi:10.1016/j.actbio.2019. 11.013

${ }^{31}$ S.-I. Inoue, M. Yamasaki, Y. Kawamura, Oxidation behavior and incombustibility of molten $\mathrm{Mg}-\mathrm{Zn}-\mathrm{Y}$ alloys with $\mathrm{Ca}$ and $\mathrm{Be}$ addition, Corrosion Science, 149 (2019), 133-143, doi:10.1016/j.corsci. 2018.12.037

${ }^{32}$ Z. Weimin, S. Yong, L. Haipeng, L. Chunyong, The effects of some elements on the igniting temperature of magnesium alloys, Materials Science and Engineering: B, 127 (2006) 2, 105-107, doi:10.1016/ j.mseb.2005.09.064

${ }^{33}$ J. F. Fan, G. C. Yang, Y. H. Zhou, Y. H. Wei, B. S. Xu, Selective Oxidation and the Third-Element Effect on the Oxidation of $\mathrm{Mg}-\mathrm{Y}$ Alloys at High Temperatures, Metallurgical and Materials Transactions A, 40 (2009) 9, 2184-2189, doi:10.1007/s11661009-9874-5 